\section{Ks. Andrzej Posadzy}

Uniwersytet Szczeciński, Szczecin

aposadzy@op.pl

DOI: http://dx.doi.org/10.12775/BPTh.2016.003

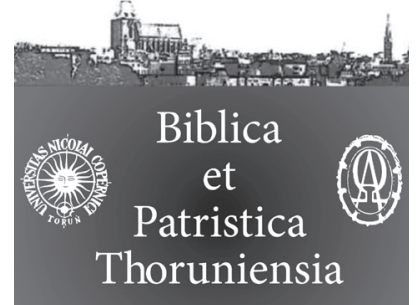

9 (2016) 1: 63-81

ISSN (print) 1689-5150

ISSN (online) 2450-7059

\title{
Czas odpoczynku w Chrystusie, obecnym w Kościele. Tradycja i redakcja Dz 3,19-21
}

\section{Refreshing time in Christ, present in the Church. Tradition and redaction of Acts 3:19-21}

Streszczenie. Eschatologia Nowego Testamentu jest niezwykle ważnym obszarem badań i analiz wielu biblistów i teologów. Wśród tekstów, które są przedmiotem tych badań, jest fragment Dziejów Apostolskich, który zawiera w swej treści drugie misjonarskie przemówienie Piotra. Wzywa on w nim słuchaczy do nawrócenia i czynienia pokuty. Motywem przewodnim słów Piotra jest proklamacja bliskości Sądu Ostatecznego i związanego z nim powrotu Chrystusa. Zbawienie eschatologiczne będzie najwyższym aktem dopełnienia się historii świata. Jezus powróci jako Ten, w którym wypełnią się wszystkie zapowiedzi Pisma. Do realizacji tych zapowiedzi brakuje jedynie uniwersalnego nawrócenia wszystkich, do którego wzywa się „w te dni”. „Te dni” są okresem misjonarskiego trudu, a dni głoszenia Łukasz nazywa „dniami orzeźwienia” i „czasem ochłody” - mesjańskim czasem eschatologicznym.

Abstract. The subject of this article is the history of redaction and theological interpretation of a passage from the Acts of the Apostles which is a part of St. Peter's second missionary speech. In the main part of his speech, St. Peter calls his listeners to repent and to do penance. The penance should be done in the imminent perspective of the Lord's Day. It should be noted that this passage is extremely important for the correct understanding of the Christology of the nascent Church. Primarily, it is important for the accurate understanding of the development of eschatological thought of the first century-Christianity. This passage announces the second coming of Christ, whom the "heaven must receive until the times of restitution of all things" (Acts 3:21). Particularly, the subject of this article is the expression from the Acts of the Apostles 3:20, speaking about the "days of refreshing" or "refresh time". That days should be expected by the Church and they will last until the second coming of Jesus Christ. The expression is so unique that there is no analogical one in the texts of the New Testament neither in the intertestamental Jewish literature. Moreover, the expression is crucial for correct understanding of the Christian eschatology. By its content the expression 
is connected with the larger topic, namely, with the issue of "the renewal of everything (apokatastasis) in Christ".

Słowa kluczowe: Dzieje Apostolskie; eschatologia; „dni orzeźwienia”; „czas ochłody”.

Keywords: Acts of the Apostles; eschatology; "days of refreshing"; "refresh time".

Tiniejsza praca jest ukazaniem historii redakcji oraz próbą interpretacji teologicznej fragmentu tekstu z Dziejów Apostolskich, który stanowi niewielką część drugiego misjonarskiego przemówienia Piotra. W swej zasadniczej treści Apostoł wzywa w niej słuchaczy do nawrócenia oraz czynienia pokuty, dokonywanej w perspektywie bliskości dnia Pańskiego ${ }^{1}$.

Trzeba zaznaczyć, że fragment ten jest niezwykle istotny dla zrozumienia chrystologii rodzącego się Kościoła, przede wszystkim dla właściwej percepcji rozwoju myśli eschatologicznej pierwszego wieku chrześcijaństwa ${ }^{2}$. W rzeczonym fragmencie znajduje się zapowiedź powtórnego przyjścia Chrystusa, którego, jak głosi tekst, „niebo musi zatrzymać aż do czasu odnowienia wszystkich rzeczy" (Dz 3,21) ${ }^{3}$.

Pojawiające się w tekście problemy dotyczą przede wszystkim tradycji, w której zrodziła się ta myśl oraz środowiska jej pochodzenia. Podstawowy problem można zawrzeć w pytaniu: czy koncepcja nieodległego nadejścia dnia Pańskiego jest autorstwa Łukaszowego, czy raczej jest powiązana $\mathrm{z}$ tradycją chrześcijańską pierwszych wspólnot. Należy zapytać, czy mamy w tym fragmencie do czynienia z tzw. Traditionsstück redakcyjnego dzieła Ewangelisty. Teologowie zastanawiają się, na ile przekaz autora jest jego oryginalnym dziełem a ile jest w nim elementów zapożyczonych z pierwotnej myśli teologicznej.

W sposób szczególny przedmiotem zainteresowania niniejszej pracy będzie sformułowanie, zawarte w wierszu dwudziestym tego fragmentu, mówiące o „dniach ochłody” albo „czasie orzeźwienia”, których Kościół ma się spodziewać i które będą trwały aż do dnia powtórnego nadejścia Pana. Jest to sformułowanie o tyle istotne, że nie znajduje żadnej analogii ani w tekstach Nowego Testamentu ani w dziełach literatury międzytestamentalnej. Posiada jednak

1 Najlepszą syntezę problematyki Dz 3,19-21 zaprezentował: A. Barbi, Il Cristo celeste presente nella Chiesa, s. 11-180.

2 Por. G. Lohfink, Christologie und Geschichtsbild in Apg. 3,19-21, s. 223. Jako przykład można zaprezentować twierdzenie J.A.T. Robinsona: „As a christological formulation it represents no more than a fossil, a residual survival of purely historical interest" (J.A. T. Robinson, Jesus and His Coming, s. 152).

3 Por. E. Grässer, Acta Forschung seit 1960, s. 2-4. 
kolosalne znaczenie dla zrozumienia eschatologii chrześcijańskiej, bowiem treściowo łączy się z tematem „odnowienia wszystkiego (apokatastasis) w Chrystusie”. W historii Kościoła termin apokatastasis wywołał ogromną polemikę, dotyczącą w pierwszym rzędzie nadziei zbawienia wszechświata. Poczynając od Orygenesa, głoszącego naukę o zbawieniu wszystkich bez wyjątku, aż do tezy o istnieniu pustego piekła, teologia w swoich rozważaniach opierała się właśnie na słowie apokatastasis jako terminie potwierdzającym ten tok rozumowania ${ }^{4}$.

4 Orygenes (185-254) pochodził z Aleksandrii, a jego rodzice byli chrześcijanami. Był wybitnym teologiem, który łączył znajomość Biblii i greckich traktatów filozoficznych, zwłaszcza Platona, neopitagorejczyków i stoików. Oskarżony o herezję i potępiony przez Synod Aleksandryjski, został pozbawiony stanowiska naczelnika szkoły katechetów i usunięty z Aleksandrii. Zamieszkał później w Cezarei, gdzie założył szkołę, która wywarła wpływ na innych myślicieli. Na system filozoficzny Orygenesa złożyły się trzy elementy: 1/ Bóg i jego objawienie w stworzeniu; 2/ upadek stworzenia; 3/ powrót przez Chrystusa do stanu pierwotnego. Według Orygenesa Bóg jest daleki i abstrakcyjny, niepojęty w swojej istocie, ale zarazem jedyny, niezmienny, nieskończony, niematerialny - w przeciwieństwie do rzeczy doczesnych, które są różnorodne, zmienne, skończone i materialne. Bóg jest dobrocią i miłością. Natomiast Chrystus-Logos jest hipostazą bytu, „drugim Bogiem”, a pierwszym szczeblem w przejściu od Boga do świata, od jedności do mnogości, od doskonałości do niedoskonałości. Wyłonił się z Boga, a z kolei z niego wyłonił się świat. Jest On nie tylko stwórcą świata, lecz także jego Zbawcą. Orygenes uważał, że świat powstał całkowicie z Boga. Jego najdoskonalszą część stanowią duchy, ale nawet materia jest Bożym tworem. Zgodnie z myślą grecką, miał to być świat, który został stworzony odwiecznie, a więc nie mający początku, podobnie jak Bóg. Orygenes uzasadniał swój pogląd założeniem, że odkąd istnieje Bóg, musiało też istnieć Jego pole działania. Świat jest więc wieczny, ale nie jest wieczna żadna $\mathrm{z}$ jego postaci; ten określony świat, $\mathrm{w}$ którym żyjemy, kiedyś powstał i kiedyś zginie, ustępując miejsce nowemu. Różni się zaś od wszystkich innych tym, że właśnie w nim Logos stał się Człowiekiem. Orygenes sądził, że duchy zostały stworzone odwiecznie, wraz z materialnym światem, a więc są nieśmiertelne i mają własną preegzystencję. Zostały obdarzone wolnością, z której korzystają dla dobra lub zła. Istnieją duchy niższe i wyższe, dobre oraz złe - jest to skutek ich wolności, a łączy je wspólna natura. Można powiedzieć, że anioły poszły za Bogiem, a ludzie przeciw niemu. Ich upadek stał się przełomem w dziejach świata, bo poniżył duchy, złączywszy je z materią. Orygenes uważał bowiem, że właśnie na skutek upadku dusza złączyła się z ciałem. Wierzył przy tym, że moc Boga zdoła przeważyć nad materią i złem i przez Chrystusa-Logosa wszystkie duchy zostaną zbawione. Po odpadnięciu od Boga nastąpi drugi okres dziejów świata - nawrócenie. Zło bowiem jest ostatecznie tylko negatywne, jest odwróceniem od Boga, od doskonałości i pełni bytu; aby je usunąć, trzeba nawrócić duchy do Boga. Osiągnięcie tego celu umożliwia poznanie, a to upatrywał Orygenes w nauce chrześcijańskiej. Uważał, że końcem dziejów będzie apokatastaza - powrót wszechrzeczy do pierwotnego źródła, do Boga. 


\section{Problemy tekstualne ${ }^{5}$}

W powyższej perykopie należy na pierwszym miejscu dostrzec problemy dotyczące kompozycji i struktury całej wypowiedzi Piotra, szczególnie w jej końcowej części ${ }^{6}$. Po wezwaniu do pokuty dla odpuszczenia grzechów (w. 19) należałoby oczekiwać cytatu biblijnego, potwierdzającego to wezwanie. Tymczasem kolejne wiersze przynoszą wykład kerygmatyczny Piotra (ww. 20-21). Dopiero po tych eksplikacjach i wywodach autor przytacza fragment ze Starego Testamentu (Pwt 18,15; Kpł 23,29) ${ }^{7}$.

Poza tymi kwestiami pojawiają się problemy dotyczące natury przekazu myśli Apostoła. Sformułowanie „pokutujcie więc ... aby też [Bóg] posłał wam zapowiedzianego Mesjasza" nie pochodzi z obszaru literackiego pierwotnego chrześcijaństwa, brakuje go również w pismach judaistycznych. Zamiast o Zmartwychwstałym, co byłoby oczywiste (zob. Dz 3,15), tekst mówi o Chrystusie, przebywającym w niebie. Misja Jezusa, opisana w w. 20, jest diametralnie inna niż ta, którą określa w. 26 i cały Nowy Testament. Księgi nowotestamentalne opisują posłannictwo Jezusa w kategoriach obdarowania człowieka nadzieją życia wiecznego, tutaj mamy opis, mówiący o nadciągającym czasie dni ostatecznych. Zamiast zwyczajowych terminów, które Nowy Testament stosuje przy tekstach eschatologicznych, fragment Dziejów Apostolskich używa koncepcji typu kairoi anapsykseōs czy też chronōn apokatastaseōs. Formuły te nie wiążą się w tekście Łukasza ani $\mathrm{z}$ tematyką poruszaną uprzednio ani po niej następującą ${ }^{8}$.

5 W kwestii problemów tekstualnych w: A. Barbi, Il Cristo celeste presente nella Chiesa, 34-44; F. Hahn, Christologische Hoheitstitel, s. 184-185.

6 Por. J. Dupont, Les discours de Pierre dans les Actes, s. 359.

7 Por. O. Bauernfeind, Die Apostelgeschichte, s. 65-66.

8 Pomocnym w rozwiązaniu ostatniej trudności może być tekst Malachiasza $(3,23)$, gdzie sformułowanie apokathistanein jest wypowiedziane w stronę „posłańca” (apostello) i odnosi się bezpośrednio do eschatologicznej funkcji Eliasza („Oto Ja poślę wam proroka Eliasza przed nadejściem dnia Pańskiego, dnia wielkiego i strasznego”). W takim przypadku imię Eliasza zostałoby zastąpione tytułem Jezusa jako Mesjasza. Również sformułowanie kairoi anapsykseōs może być przywołaniem Syr 48,10 („O tobie [Eliaszu] napisano, żeś zachowany na czasy stosowne, by uśmierzyć gniew przed pomstą, by zwrócić serce ojca do syna, i pokolenia Jakuba odnowić”). Jest to jeden z podstawowych tekstów Starego Testamentu mówiący o przyjściu Eliasza na końcu czasów. Można zatem przypuszczać, że w dziele Łukaszowym mamy do czynienia z chrystianizacją tradycji o eschatologicznym przybyciu Eliasza. Ciekawy jest również fakt, że taką samą funkcję czasownika apokathistemi Ewangelie odnoszą do postaci Jana Chrzciciela (Mk 9,12; Mt 17,11), który ma przybyć 


\section{Analiza stylistyczna perykopy}

Nie ma wątpliwości, że wiele sformułowań znajdujących się w tym fragmencie Dziejów Apostolskich należy do słownictwa Łukasza. Szczególnie pierwsza część tekstu prezentuje formuły typowe dla trzeciego Ewangelisty. „Pokutujcie więc i nawróćcie się" to punkt odniesienia dla wszystkich przemówień misyjnych, zawartych w Dziejach $(2,38 ; 5,31 ; 10,43 ; 13,38)$. Również w Ewangelii spotykamy takie sformułowanie jako oryginalnie stwierdzenia Łukasza ${ }^{9}$. Wyrażenie „aby grzechy wasze zostały zgładzone” jest tradycyjną formułą antyczną, którą Łukasz zaczerpnął z istniejących już utworów literackich, być może pism Starego Testamentu ${ }^{10}$. Niektórzy teologowie uważają jednak, że mamy tutaj do czynienia z typową formułą Łukasza, w jego dziełach bowiem często przewija się sekwencja: pokuta-nawrócenie-odpuszczenie grzechów (Łk 3,3; Dz 2,38; $26,18 ; 24,47 ; 5,31)^{11}$. Eksaleifthēnai to hapax legomenon w dziele Łukaszowym. Równie rzadko występuje on w całym Nowym Testamencie (Kol 2,14; Ap 3,5; $7,17 ; 21,4)^{12}$. Dość często spotykamy go natomiast w Starym Testamencie, gdzie łączy się z terminem hamartía (Ps 108,14; Jer 18,23) albo pokrewnym jemu obszarem semantycznym (2 Mch 12,42; Ps 50,11: Syr 46,20; Iz 43,25). Można więc słusznie wnioskować, że termin użyty przez Łukasza, został zaczerpnięty z tradycji Septuaginty.

Kolejne zdanie, które Łukasz zamieścił w swoim dziele, będzie przedmiotem wnikliwej analizy. Wcześniejsza wypowiedź Ewangelisty wspominała o pokucie i nawróceniu człowieka. Ich skutkiem mają być „nadchodzące od Pana

jako nowy Eliasz: O. Bauernfeind, Tradition und Komposition in dem Apokatastasisspruch Apg. 3,20s., s. 13-23.

9 Badania statystyczne wskazują, że słowo metanoein/metanoia występuje 11 razy w Dziejach i 14 w Ewangelii. W tej drugiej tylko czterokrotnie słowo to jest użyte w Ewangeliach synoptycznych (3,3=Mk 1,4; Mt 3,2:3,8=Mt 3,8;10,13=Mt 11,21;11,32=Mt 12,41). Dziesięciokrotnie występuje w Ewangeliach jako Sondergut Łukasza. Również epistrefein/epistrofe jest typowym terminem Ewangelisty. Występuje 7 razy w Ewangelii i 12 razy w Dziejach.

10 Por. F. Hahn, Christologische Hoheitstitel, s. 184-186.

11 Por. K. Kliesch, Die Heilsgeschichtliche Credo, s. 24.

12 Termin exaleiphō oznacza „zgładzić”, „zniszczyć”. W Nowym Testamencie określa ono działanie Boga usprawiedliwiającego człowieka. („nawróćcie się więc i powróćcie do Niego, aby zgładził wasze grzechy” [Dz 3,19]; „On [Jezus] zniszczył obciążające nas zestawienie długów [Kol 2,14]). W Apokalipsie autor mówi o „wykreśleniu” imienia z księgi życia (Ap 3,5) albo „otarciu” łzy smutku (Ap 7,17), por. J. Lambrecht, exaleiphō, s. 1239. 
dni ochłody”. Termin hopos an jest formą introdukcji do tego zdania ${ }^{13}$. Jest formułą często spotykaną w LXX, przede wszystkim w Psalmach i Pentateuchu ${ }^{14}$. W Nowym Testamencie występuje jedynie czterokrotnie. Wydaje się zatem, że pojawienie się tego zwrotu w tekście Dziejów jest cytatem ze Starego Testamentu lub innego dzieła literatury przedchrześcijańskiej. W tłumaczeniach frazy hopos an spotykamy rozbieżności, można ją bowiem oddać w formie „jakkolwiek”, „może (Bóg) sprawi” lub „aby nadeszły”, „aby przyszły”, „gdyby przyszły", "gdy nadejdą". Wydaje się, że formuła hopos an posiada tutaj (podobnie jak cały w. 20a) wymiar parenetyczny. Definiuje główną tematykę zdania, którą jest nawoływanie do nawrócenia. Należy więc do słownictwa typowo apokaliptycznego, podobnego do tego, jakie można znaleźć w wielu innych tekstach eschatologii pozachrześcijańskiej. Przy objaśnieniu tej formuły szczególnie pomocne wydają się teksty zawarte w Syryjskiej Apokalipsie Barucha, które mówią w wytrwałości w zachowaniu Prawa. Teksty te głoszą, że jedynie przestrzeganie Bożych przykazań ustrzeże ludzi od eschatologicznej katastrofy $(32,1)^{15}$. Inny fragment twierdzi, że wierność Prawu zainicjuje nowy czas obfitości i udział w dziele zbawienia (44,7; 46,5-6). Jeszcze inny zawiera obietnicę rekonstrukcji Izraela $(77,6)$ i zbawienia eschatologicznego.

Zdanie z Dz 3,20 mówi następnie o motywacji do nawrócenia i pokuty. Ma się ona spełnić ze względu na zgładzenie grzechów i zesłanie „orzeźwienia”, „ochłody”. Takie zesłanie ma się dokonać dosłownie „sprzed oblicza Pana” (apo prosopou tou kyriou). Frazę apo prosopou można spotkać w Nowym Testamencie sześciokrotnie a w Liście do Tesaloniczan znajduje się formuła identyczna do tej z Dziejów (2Tes 1,9). Zazwyczaj używana jest ona w sensie oddalenia, oddzielenia, ukrycia albo ukazania czegoś. Bardzo często występuje w tekście LXX (270 razy) $)^{16}$ ale tylko pięciokrotnie użyta jest w rozumieniu Dziejów Apostolskich $^{17}$. Najbliższe znaczeniowo jest zdanie znajdujące się w Księdze Liczb

13 Samo hopōs występuje w Nowym Testamencie 53 razy, przede wszystkim u Mateusza. Zazwyczaj stosuje się go przymiotnikowo („w ten sposób”, „jak” albo przysłówkowo („ażeby”, „aż do”). Podkreśla albo cel albo finał wyrażonej myśli („a Twoja duszę miecz przeszyje, aby zostały ujawnione przewrotne myśli wielu” [Łk 2,35]). Bywa często używany po czasownikach stosowanych w modlitwach albo wypowiedziach władz religijnych (Mt 12,14).

14 Por. L. Cerfaux, Citations scripturaires et tradition textuelle, s. 49.

15 „Wy zaś jeżeli przygotowaliście nasze serca, aby zbierać z nich owoc prawa, otoczy was opieka w owym czasie, w którym przyjdzie Potężny, który wstrząsa każdym stworzeniem" (ApBaSyr 32,1).

16 Haenchen mówi o „septuagintalizmie” tego terminu, por. E. Haenchen, Die Apostelgeschichte, s. 168.

17 Por. G. Lohfink, „Christologie”, s. 232. 
(Lb 17,11). Można przypuszczać, że całe wyrażenie Łukasza, zawarte w Dziejach jest unikalne $\mathrm{w}$ Biblii i zostało ono zaczerpnięte $\mathrm{z}$ jakiegoś nieznanego bliżej dzieła.

Kolejny werset Dziejów jest formą obietnicy eschatologicznej i przepowiada przybycie „zapowiedzianego Mesjasza, Jezusa” (20b). Należy zauważyć, że werset ten w żaden sposób nie jest kontynuacją zdania poprzedniego i stylistycznie wyraźnie się od niego odróżnia. Zmienia się przede wszystkim podmiot zdania. Niektórzy bibliści przypuszczają, że wiersze 19b-21a są wtrętem Łukasza we wcześniej napisany jakiś tekst proweniencji semickiej. Brakuje jednak solidnych podstaw teologicznych aby można było potwierdzić taką tezę ${ }^{18}$. Słowo „posłał”, obecne w tym fragmencie, stwarza obiektywnie najwięcej trudności interpretacyjnych. Na kartach Nowego Testamentu czasownik ten jest przypisywany działaniu Jezusa i Jego ziemskiej misji głoszenia Ewangelii. Jedyną w swoim rodzaju jest powyższa wypowiedź, która jest wyrazem wizji teocentrycznej całej misji Jezusa. Faktem jest, że w Dziejach Apostolskich spotykamy tendencję autora do uzależniania całego posłannictwa Jezusa od woli Boga Ojca. Dzieło Łukasza często podkreśla, że to Ojciec wysłał Jezusa na misję (Dz 13,23), że posłał Słowo synom Izraela $(10,36)$. Jezus namaszczony przez Boga $(10,38)$, został ofiarowany dla głoszenia słowa i czynienia cudów $(2,22)$, umarł na krzyżu według planu Bożego $(2,23 ; 3,18)$. Został wskrzeszony z martwych $(2,24.32 ; 13,34 ; 3,15 ; 5,30 ; 10,40 ; 13,30)$. Dzięki mocy Boga mógł się ukazywać $(10,40)$, został wywyższony $(2,33 ; 5,31)$, zesłał Ducha $(2,33 ; 5,32)$ i stał się sędzią żywych i umarłych $(10,42 ; 17,31)$. W przypadku Dz 3,20b słowo „posłał” byłoby więc dopełnieniem tej listy, ponieważ wskazywałoby na obietnicę, o której tekst wspomina w dalszej jego części: najpierw obietnicę skierowaną do Mojżesza $(3,22)$ a później obietnicę błogosławieństwa, daną Abrahamowi $(3,25)$. Kolejne sformułowanie, mówiące o posłaniu Chrystusa, prezentuje czasownik prokeheirismenon (hymin). Czasownik ten jest bez wątpienia Łukaszowy. Spotykamy go jeszcze w Dz 22,14 i 26,16.

Cały kolejny wiersz tekstu Łukaszowego wydaje się być zapożyczeniem i przepracowaniem jakiegoś tradycyjnego materiału, będącego wcześniej istniejącym dziełem. Zdanie brzmi: „którego niebo musi zatrzymać aż do czasu odnowienia wszystkich rzeczy, co od wieków przepowiedział Bóg przez usta swoich świętych proroków". Wstępne wyrażenie hon jest typowym dla Łukasza. Jest to określenie występujące najczęściej w treściach kerygmatycznych, prezentujących chrystologię Dziejów Apostolskich (2,24.36; 3,13.15; 4,10; 5,30; $10,40 ; 13,37)$. Czasownik dei w słowniku Łukasza jest bardzo charakterystyczny

18 Por. F. Hahn, Christologische Hoheitstitel, s. 185. 
i często stosowany, zwłaszcza w opisach historyczno-zbawczych ${ }^{19}$. Jako określenie chrystologiczne jest już obecne w tradycji przedłukaszowej i spotykane przy opisach pasji (Mk 8,31; Mt 16,21; Łk 9,22). Łukasz poszerza horyzont znaczeniowy tego słowa i określa nim fakt pobytu Jezusa w świątyni (Łk 2,49), głoszenie słowa w innych miastach (Łk 4,43), podróż w stronę Jerozolimy $(13,33)$. W Dziejach Apostolskich najczęściej określa czas odpoczynku i postoju Jezusa w domu $(1,16.21 ; 4,12 ; 9,6.16 ; 14,22 ; 19,21 ; 23,11)$.

Rzeczownik ouranon jest spotykany na kartach dzieł Łukaszowych, choćby w opisach sceny wniebowstąpienia ( $Ł k$ 24,50-51; Dz 1,9-11). Posiada wiele znaczeń. Jednakże termin ten nie należy do tradycyjnych sformułowań Ewangelisty, ponieważ należy on do typowych i stereotypowych określeń, stosowanych przez autorów przy opisie Wniebowstąpienia Chrystusa (tzw. Entrückungsmotiv). Tymczasem w przypadku Dziejów mamy do czynienia z określeniem nieba jako miejsca czasowego przebywania Chrystusa ${ }^{20}$.

Interesującym, z punktu widzenia leksykalnego, jest czasownik dehomai. Sposób, w jaki został użyty przez Łukasza wskazuje na podobieństwa z utworami pogańskiej literatury greckiej, być może utworów Platona lub Sofoklesa. W dziełach filozofów i poetów czasownik „otrzymywać”, „przyjmować” dotyczy przedmiotów, takich jak listy, podarunki albo złożone ofiary. Są wyrazem gościnności, chęci przyjęcia kogoś pod własny dach (tak np. Ksenofont, Homer, Plutarch). Rzadko występuje w kontekstach religijnych, w których podmiotem jest jakieś bóstwo przyjmujące ofiary i modlitwy ludzi.

Do języka Ewangelisty na pewno nie należy termin apokatastasis, ponieważ jest to hapax legomenon całego Nowego Testamentu. Nie spotykamy go również w wersji greckiej Starego Testamentu (LXX). Dwukrotnie na stronach Nowego Testamentu pojawia się słowo apokathistemi, połączone z panta i opisujące nadejście Eliasza, który „wszystko naprawi” (Mt 17,11; Mk 9,12). Również w tym przypadku zwrot apokatastasis panton odnosiłoby się do spełniania się obietnic prorockich.

\section{3. „Dni ochłody” (Dz 3,20a)}

Rzeczownik anapsyhein, który przysparza teologom wiele problemów interpretacyjnych, należy do kluczowych sformułowań eschatologicznych Łukasza ${ }^{21}$. Ewangelista obwieszcza w nim prawdę o konieczności nawrócenia w obliczu

19 Por. H. Conzelmann, Die Mitte der Zeit, s. 142-144.

20 Por. G. Lohfink, Die Himmelfahrt Jesu, s. 195.

21 Por. A. Barbi, Il Cristo celeste presente nella Chiesa, s. 46-75. 
nadchodzących dni ostatecznych. Autor obiecuje przybycie Chrystusa a wraz z nim nadejście „czasu pocieszenia”. Sformułowanie kairoi anapsykseōs tłumaczone jest zazwyczaj poprzez takie zwroty, jak: „czasy orzeźwienia”, „chwile ochłody”, „pokrzepienia”. Całe zdanie wydaje się być stałą formułą, która zapowiada precyzyjny moment a którego nie ma potrzeba dodatkowo opisywać. W swej wymowie teologicznej sformułowanie wzywa jednoznacznie chrześcijan do nawrócenia. Wyrażenie kairoi anapsykseōs jest hapax legomenon całego Nowego Testamentu. Termin anapsyksis spotykamy jeden raz w Księdze Wyjścia (LXX), ale nie jest tam on powiązany z wymiarem czasowym („Faraon odetchnął z ulgą, lecz trwał w uporze i nie usłuchał ich, co zresztą Pan zapowiedział”, 8,11). Może być zatem traktowane ogólnie jako wyrażenie „pozabiblijne”.

W Nowym Testamencie jeden raz spotyka się termin podobny do anapsyksis i znajduje się on w Liście do Tymoteusza $(2 \mathrm{Tm} 1,16)$. W wierszu tym pojawia się termin anapsyhein, jednakże autor używa go w kontekście pocieszenia Apostoła znoszącego trud ewangelizacji. Apostoł dziękuje Onezymowi za pociechę, jakiej doznał w czasie swojego pobytu w więzieniu w Efezie i Rzymie. Wewnątrz Starego Testamentu (LXX) termin anapsyksis spotka się w Księdze Wyjścia i odnosi się on do plagi żab, nękających mieszkańców Egiptu. Po uwolnieniu od tego nieszczęścia faraon stwierdza, że „ustąpił ucisk” (Wj 8,11). Teologowie dostrzegają w tym tekście znaczenie teologiczne: Bóg poprowadził swój lud do odpoczynku, wolności, uwalniając od strachu, który ich ogarniał. Można sugerować, że termin anapsyksis opisuje przejście od sytuacji bólu i cierpienia do stanu wolności i radości.

Warto zwrócić uwagę na występowanie w Biblii terminów zbliżonych znaczeniowo do anapsyhein, szczególnie słów z rdzeniem anapsh- w tekstach Septuaginty. Czasownik ten pojawia się kilkakrotnie i jest greckim tłumaczeniem terminów hebrajskich. W Księdze Wyjścia tekst mówi o nakazie odpoczynku szabatowego: „przez sześć dni będziesz się krzątać wokół swoich zajęć, a w siódmym dniu odpoczniesz" $(23,12)$. Hebrajski termin naphasz, który autor LXX tłumaczy poprzez anapsyhein, oznacza tutaj „odpocząć po trudach”. Podobne użycie czasownika naphasz można spotkać w Księdze Machabejskiej (2 Mch 4,46 i 13,11). W Księdze Sędziów Samson, po zwycięstwie nad Filistynami, zostaje pokrzepiony wodą, którą Bóg wyprowadził ze skały. Jak mówi tekst, „kiedy Samson się jej napił, wróciły mu siły i znowu się ożywił” $(15,19)$. Czasownik hajah, użyty w formie qal oznacza powracające człowiekowi siły witalne. Księga Samuela opisuje przypadek Saula, na którego Bóg zesłał złego ducha. Kiedy go opanowywał Dawid „brał cytrę i grał na niej. To przynosiło Saulowi ulgę; król się uspokajał i zły duch odstępował od niego" (1 Sam 16,23). Podobny sens użycia czasownika anapsyhein spotykamy w Drugiej Księdze Samuela, gdzie czytamy, że po trudnej podroży Dawid i jego towarzysze „odpoczęli, ponieważ 
byli bardzo zmęczeni” $(16,14)$. W jednym z Psalmów zawarta jest modlitwa do Boga z prośbą, aby oddalił swoją karę. Modlitwa kończy się słowami: „Pozwól mi ochłonąć" (Ps 39,14). Użyty tutaj czasownik balag w odmianie hiphil oznacza „bycie szczęśliwym, radosnym”.

Z całej analizy powyższych tekstów Starego Testamentu można wysnuć następujący wniosek: wszystkie opisują sytuację, w której Bóg prowadzi swój naród do odpoczynku po trudach, uwalnia od wszelkich obaw, które go nękają. Należy zwrócić uwagę na fakt, że pole semantyczne rdzenia anapsyh- posiada szeroki krąg: od negatywnego „uwolnić od”, aż po pozytywny: „radość, szczęście”. Wewnątrz tego pola są również takie treści znaczeniowe, jak „odpocząć”, „nabrać sił”, „ożyć”. Wniosek, jaki można wyciągnąć z dokonanej powyżej analizy, wskazuje, że żadne z podanych sensów czasownika anapsyhein, obecnego w Starym Testamencie, nie odpowiada treściowo i semantycznie użytemu rzeczownikowi anapsyksis w dziele Łukaszowym.

Formuła kairoi anapsykseōs przez niektórych teologów jest widziana w Księdze Dziejów jako określenie „chwili oddechu w momentach cierpień mesjańskich”(tak twierdzi O. Bauerfeind) ${ }^{22}$ albo „opis końca świata w którym ustanie wszelkie strapienie"(teza G. Vossa) ${ }^{23}$. W drugim przypadku autor odsyła do wizji Łukasza, w której autor pisze: „ludzie umierać będą ze strachu i z oczekiwania tego, co ma przyjść [...]. A kiedy to się stanie nabierzcie ducha i podnieście głowy" (Łk 21,26-28). Obydwie konkluzje bazują na przekonaniu, że termin kairoi anapsykseōs rzeczywiście oznacza koniec czasu cierpienia. Bauernfeind dostrzega jednak, że w wypadku tekstów Starego Testamentu, szczególnie Księgi Wyjścia, niebezpieczeństwa nie przemijają całkowicie, że są to opisy jedynie czasowego ustąpienia zagrożenia i należy obawiać się dalszego ciągu nieszczęść. Z tej analizy wyciąga wniosek, że anapsyksis, obecne w Dziejach, oznacza jedynie czasowe ustanie cierpienia, chwila, która poprzedza nadejście czasu zbawczego. Można zatem zadać pytanie o kwestię tzw. eschatologii przejściowej, na przykład typu millenarystycznego, być może obecnej wewnątrz teologii żydowskiej, którą, co prawdopodobne, przejął Łukasz.

Voss w swojej analizie tekstu Dziejów Apostolskich dokonał zestawienia tego tekstu z fragmentem Ewangelii Łukasza, w której mowa jest o cierpieniu i gratyfikacji za wytrwałość. Autor porównał termin anapsyksis z apolytrosis, obecnego w 21,26-28. Jako uzasadnienie takiego postępowania Voss wskazał na występowanie w Łk 21,26 terminu apopsyhontes („mdleć/umierać”), które jest treściowym przeciwieństwem rdzenia anapsyh ${ }^{24}$. Interpretacji tej sprze-

22 Por. O. Bauernfeind, Die Apostelgeschichte, s. 68.

23 Por. G. Voss, Die Christologie der lukanischen Schriften, s. 151.

24 Por. również: W. Grundmann, Das Evangelium nach Lukas, s. 384n. 
ciwia się jednak fakt, że wobec zbliżającego się końca ludzkość spodziewa się generalnej katastrofy, podczas gdy dla chrześcijan jest to czas zwycięstwa i wybawienia. Będzie to dzień „podniesienia głowy” i „odkupienia”. Taką interpretację można przedstawić za pomocą schematu:

w. 26: reszta ludzkości - strata - lęk przed katastrofą;

w. 28: wspólnota chrześcijańska - podniesiona głowa - oczekiwanie wybawienia.

Niektórzy bibliści dostrzegają pewien paralelizm pomiędzy anapsyksis z Dziejów Apostolskich i anesis („pocieszenie”, „ulga”, „wytchnienie”), znajdującego się w 2 Tes $1,7^{25}$. Fragment Listu do Tesaloniczan rzeczywiście posiada wydźwięk eschatologiczny, mówi bowiem o tzw. „podwójnej retrybucji”: ci, którzy teraz przysparzają innym cierpienia, będą cierpieć; ci, którzy teraz cierpią, doświadczą „ulgi/odpoczynku”26. Interpretacja Dz 3,20a jest jednak zupełnie inna: tekst nie mówi o retrybucji ani tym bardziej prześladowaniach, którym anapsykseōs położy kres ${ }^{27}$. Być może obydwa terminy anapsyksis oraz anesis korespondują ze sobą leksykalnie ale ich użycie w tekstach jest zupełnie inne.

Niektórzy teologowie, badając tekst Dziejów, próbują porównać słowo anapsykseōs $\mathrm{z}$ jego występowaniem $\mathrm{w}$ grece klasycznej. Jego obecność w literaturze pogańskiej określa zwyczajowo stan odpoczynku, przerwy w działaniu, czasami też czas ochłody/orzeźwienia. W grece pogańskiej termin kairoi anapsykseōs oznacza chwilowy czas ulgi, pociechy, który jest możliwy do osiągnięcia przez wiarę. Zazwyczaj jest stosowany w odniesieniu do działań medycznych i oznacza chwilową ulgę w cierpieniach fizycznych (tak użyte można spotkać w traktatach Hipokratesa i Galena).

Jednym z badaczy, który poświęcił swoją uwagę temu określeniu był A. Dietrich. W swych badaniach poszukiwał podobieństw kontekstualnych z greckimi opisami zwyczajów funeralnych, spotykanych w kultach misteryjnych. Wskazywał, że słowo anapsyksis w tych tekstach odnosi się do opisu błogiego stanu duszy po śmierci. Dietrich dokonał też porównań tekstów pogańskich z opisami chrześcijańskimi. Również odpowiednik łaciński terminu anapsyksis, a więc określenie refrigerare, refrigerium znalazło się w orbicie zainteresowań teolo$\mathrm{ga}^{28}$. Niestety, całość poszukiwań badawczych niewiele wniosła do zrozumienia sformułowania kairoi anapsykseōs z Dziejów Apostolskich. Wydaje się, że świat helleński żadną miarą nie wpłynął na semickie rozumienie tej frazy. Powodem

Por. E. von Dobschütz, Die Thessalonicher Briefe, s. 243.

Por. C. Masson, Les deux épitres de saint Paul aux Tessaloniciens, s. 85n.

Por. H.H. Wendt, Die Apostelgeschichte, s. 110.

Por. A. Dietrich, Nekyia, s. 95-98. 
jest przede wszystkim fakt, że zwrot kairoi anapsykseōs jest określeniem czasowym, natomiast świat grecki stosuje go w ujęciu przestrzennym.

W swoim komentarzu do Nowego Testamentu Strack-Billerbeck prezentują wiele tekstów rabinistycznych, które zawierają zwrot anapsykseōs. Pirke Aboth w jednym ze swych tekstów przywołuje sformułowanie „ochłoda w duchu”. Użyty jest on w kontekście perspektywy istnienia dwóch światów, obecnego i przyszłego i przytacza apokaliptyczne koncepcje następowania tych eonów po sobie. Eon przyszły jest scharakteryzowany właśnie poprzez sformułowanie „ochłoda ducha” a cała eschatologiczna przyszłość zwrotem „rajskie dni eonu, który ma przyjść" 29 . F. Mussner cytuje inny tekst rabiniczny, Testament Lewiego, w którym również jest mowa o „rajskiej ochłodzie”, „rajskim orzeźwieniu” $(18,4.10 .12)^{30}$. Wydaje się, że jest to jednak powiązanie zbyt ogólne i zbyt wiele znajduje się w nich elementów rozdzielających obie koncepcje: według tekstu żydowskiego czas zbawienia urzeczywistni się wewnątrz czasu teraźniejszego, obecnego $^{31}$. Poza tym podział na dwa eony wyklucza perspektywę interwencji mesjańskiej. Można zatem przypuszczać, że w tekście rabinicznym autor odwołuje się do sytuacji niebiańskiej oczekiwanej przez apokaliptykę w nowym eonie. Mowa jest zatem o „miejscu ochłody” a nie o wyjątkowym czasie, o którym mówi autor Dziejów Apostolskich.

Ostatnią próbą odnalezienia biblijnego sensu sformułowaniu kairoi anapsykseōs zaprezentował U. Wilckens ${ }^{32}$. Odwołał się w swej pracy do spekulacji eschatologicznych odnoszących się do osoby Eliasza. W tej perspektywie można dostrzec rolę Eliasza jako tego, który w dniach eschatologicznych oddala od ludzkości gniew Boży. Pisze o tym wyraźnie prorok Malachiasz: „oto poślę do was proroka Eliasza, zanim przyjdzie wielki i straszny dzień Pana” $(3,23)$. Autor łączy tę obietnicę ze sformułowaniem z Księgi Syracydesa, która również wspomina o misji Eliasza: „zawsze byłeś gotów złość i gniew powstrzymać” $(48,10)$. Konkluzja Wilckensa nie może jednak zostać zaakceptowana: tradycja o Eliaszu wskazuje wyraźnie proroka jako tego, który chwilowo powstrzymuje gniew i sąd Boga, tekst Dziejów mówi jednoznacznie o konkretnym czasie zbawienia.

Najbardziej" prawdopodobną i przejrzystą interpretację terminu kairoi anapsyksis zaprezentował G. Lohfink ${ }^{33}$. W swojej interpretacji przywołał jeden z tekstów literatury międzytestamentalnej, który znaczeniowo bardzo zbliża

29 Por. H. Strack - P. Billerbeck, Kommentar zum Neuen Testament, s. 626.

30 Por. F. Mussner, Praesentia salutis, s. 223.

31 Por. P. Volz, Die Eschatologie der jüdischen, s. 32.

32 Por. U. Wilckens, Die Missionreden der Apostelgeschichte, s. 153.

33 Por. G. Lohfink, Christologie und Geschichtsbild in Apg. 3,19-21, s. $231 \mathrm{n}$. 
się do fragmentu z Dziejów Apostolskich. Chodzi tutaj o fragment z Czwartej Księgi Ezdrasza (4 Ezd 11,46) w wersji łacińskiej: „ut refrigeret omnis terra et revertetur liberata de tua vi et speret iudicium et misericordiam eius qui fecit eam". Czasownik refrigeret jest tłumaczeniem greckiego terminu anapsykseōs, samo sam łacińskie określenie można spotkać jeszcze w Wj 23,12; Ps 38,14 oraz 2 Mch 4,46. Cały fragment 4 Ezd 11,1-12,34 nazywany jest zwyczajowo „zbiorem orła" i zawiera wizje autora i ich interpretację. W pierwszej części tej wizji (11,1-35) autor opisuje ogromnych rozmiarów orła, który wychodzi z głębin morza. Posiada trzy głowy i dwanaście skrzydeł z których wyłania się kolejnych osiem, niewielkich rozmiarów, skrzydeł. Orzeł ustanawia swoje królestwo nad mieszkańcami całej ziemi. W drugiej odsłonie (11,37-46) autor przedstawia postać lwa, który wychodzi z lasu. Lew oskarża orła o to, że jest przyczyną jego porażek i niepowodzeń, obwieszcza koniec jego królestwa i w konsekwencji wolność dla całej ziemi. Właśnie ostatni akt działania lwa jest opisany słowem anapsykseōs, które znajdujemy w Dziejach Apostolskich. Cała wypowiedź lwa, zamieszczona w Księdze Ezdrasza, przypomina dyskursy sądownicze proroków Starego Testamentu. Po wstępie i zaproszeniu do wysłuchania orędzia następuje seria oskarżeń (ww. 40-42), zapowiedź interwencji (ww. 43-44) i konsekwencje: najpierw negatywne (w. 45), a później pozytywne (w. 46) interwencji ${ }^{34}$. Ostatni werset jest opisem pozytywnych konsekwencji interwencji sądu: „uti refrigeret omnis terra et relevetur liberata de tua vi et speret iudicium et misericordiam eius qui fecit eam". W zdaniu tym pojawiają się dwa sformułowania: „znaleźć/odnaleźć spokój” oraz „odetchnąć/odpocząć”. To ostatnie można by doskonale oddać poprzez greckie anapsykseōs. Jego wymiar dopełnia doskonale fraza „od Twojej mocy”, spotykana kilkakrotnie na kartach Starego Testamentu (Wj 8,11; 1 Sm 16,23; Ps 65,12; 2 Mch 13,11 gdzie można dostrzec obraz odpoczynku po uwolnieniu z opresji).

W następującej po „zbiorze orła” interpretacji tych wydarzeń (4 Ezd 12,10-34) pojawia się teoria identyfikująca orła $z$ imperium rzymskim (obserwuje się tutaj wyraźny paralelizm z Dan 7). W kolejnej części (12,31-34) lew z opisu staje się Mesjaszem, którego Najwyższy zachował na koniec dni. On będzie Sędzią całego imperium, które zostanie zniszczone, ale Mesjasz uczyni wiele dobra tym, którzy „przeżyli w ziemi obiecanej”. Całe zdanie brzmi: „nam re-

34 U.B. Müller prezentuje cały opis inaczej: 1) prawdziwa i rzeczywista wizja orła $(11,1-35) ; 2)$ wizja lwa i jego mowa oskarżycielska $(11,36-46) ; 3)$ dodatek redakcyjny, który kontynuuje wizję orła i opisuje krótko koniec tej wizji (12,1-33a); 4) modlitwa wizjonera, która tłumaczy pochodzenie wizji (12,3b-9); 5) opis znaczenia wizji orła (12,10-31a); 6) objaśnienie figury lwa terminami mesjańskimi (12,31-35); 7) nakaz opisania wizji $(12,36-40)$; 8) konkluzja generalna i wyjaśnienia końcowe $(12,40-50)$, por. U.B. Müller, Messias und Menschensohn, s. 94n. 
siduum populum meum liberabit cum misericordia, qui salvati sunt super fines meos, et iucundabit eos, quoadusque veniat finis, dies iudicii, de quo locutus sum tibi ab initio" (12,34). W zdaniu tym pojawia się fraza „nam residuum populum meum liberabit cum misericordia" a zaraz po niej zdanie mówiące o Mesjaszu, który uszczęśliwi wszystkich, którzy przeżyli („et iucundabit eos”). Adresatami akcji zbawczej Mesjasza są tutaj wszyscy, którzy przeżyli, reszta narodów, wszyscy ci, którzy przezwyciężyli lęki i strapienia czasu eschatologicznego a teraz pragną doświadczać szczęśliwego losu Izraela. Ten czas mesjańskiej szczęśliwości będzie trwał aż do dnia sądu.

Tekst Księgi Ezdrasza mówi zatem o jakimś przedziale czasu, który będzie istniał pomiędzy zniszczeniem sił nieprzyjacielskich (Księga ma tu na myśli Imperium Rzymskie) a dniem Bożego sądu. Ten okres czasu jest oznaczony słowem refrigerium, które zostało już przetłumaczone poprzez terminy „odpoczynek” i „radość”. Wydaje się, że czasownik anapsyksis jest subiektywną refleksją autora w opisie sytuacji wyzwolenia, uwolnienia, czasu mesjańskiego. Czas ten jest zdominowany działaniem Mesjasza. Tym, który korzysta $\mathrm{z}$ daru czasu Mesjasza, jest w pierwszym rzędzie cała ziemia, a później reszta ludu. Może się to wydawać paradoksalne, jednakże w kosmologii Ezdrasza świat jest utożsamiany z ludem, a ten z Izraelem (zob. 4 Ezd 13,26; 6,55.59). Jasno można zatem stwierdzić, że lud i Izrael to określenia tożsame i że to właśnie ten ostatni jest przedmiotem działań Ezdraszowego Mesjasza.

$\mathrm{Z}$ analizy powyższych tekstów można zatem wnioskować, że opisy orła i lwa w tzw. „wizji orła” są tak naprawdę opisami czasów mesjańskich. Wiadomym jest, że Księga Ezdrasza została zredagowana w celu wzbudzenia narodowych nadziei i wiary w Bożą opiekę. Według tych proroctw ukaże się Mesjasz, który stanie się oswobodzicielem ludu Izraela i twórcą narodowego królestwa. Nie jest to przepowiednia czysto polityczna, zawiera bowiem również elementy religijne. Przewodnia myśl Księgi posiada wymiar mesjanizmu królewskiego na wzór tego, który reprezentują Psalmy Mesjańskie (np. Ps 17, 23-50; 18,6-9). W 4 Ezd 11,46 zbawienie jest skutkiem Bożego miłosierdzia, który pragnie nie tyle destrukcji świata ile raczej zainicjowania królestwa teokratycznego. W 4 Ezd 12,34 tymczasem stan szczęśliwości, zainaugurowany przez Mesjasza, będzie trwał do dnia sądu Bożego. Pierwszy tekst prezentuje perspektywę dwóch eonów ziemskich: koniec starego czasu, którego wyobrażeniem jest zniszczenie orła i jego królestwa i początek działania wolnościowego Mesjasza, który rozpoczyna swoje panowanie od restauracji królestwa teokratycznego. W drugim tekście natomiast spotykamy Mesjasza, który działa w czasie przed dniem końcowym świata (intermedio). „Koniec” zatem w pierwszym tekście związany jest ze zniszczeniem starego porządku, które zostanie wykonane 
przez Mesjasza a w drugim z sądem Bożym, powiązanym z czasowym królestwem Mesjasza.

Dla lepszego zrozumienia terminu anapsyksis z Dziejów Apostolskich, warto jest przyjrzeć się postaci Mesjasza z Księgi Ezdrasza ${ }^{35}$. W kilku tekstach znajduje się jego postać, a najważniejszym fragmentem opisującym jego osobę jest tzw. „wizja Syna Człowieczego” (4 Ezd 13,1-13.25-53). Proroctwo przedstawia osobę Mesjasza, zbawiciela wszelkiego stworzenia i przywódcę tych, którzy przeżyli (reszty). Nikt go nie poznał aż do momentu, kiedy wyszedł z ukrycia (odmętów morskich) w określonym czasie. Tłum atakujący jego osobę reprezentuje wszystkie narody świata. Mesjasz objawia się na górze Syjon, z wysokości której oskarża wrogie nacje a następnie dokonuje ich wytępienia. Pozostaje tylko tłum pragnący żyć w pokoju, a tworzy go pozostałych dziesięć pokoleń Izraela, które powracają z odległej ziemi w celu zamieszkania w Palestynie, razem z tymi, którzy ocaleli z wojny narodów ${ }^{36}$.

Interpretacja tego opisu kumuluje się wokół postaci Mesjasza, który najpierw dokonuje dzieła zniszczenia narodów, a następnie gromadzenia pozostałych, pokojowo nastawionych, szczególnie z dziesięciu pokoleń Izraela. Dobitnie sygnalizuje to jeden $\mathrm{z}$ wersetów: “ipse est quem conservat Altissimus multis temporibus, qui per semet ipsum liberabit creaturam suam, et ipse disponet qui derelicti sunt" (4 Ezd 13,26). Werset wyraźnie stwierdza, że Mesjasz będzie narzędziem boskiego działania („per semet ipsum liberabit creaturam suam"). Dokona nie tyle wybawienia Izraela od zła, ile od grzesznych narodów. Widać zatem wyraźnie pewnego rodzaju mesjańskie oczekiwanie Izraela. Być może mówi się tutaj, zgodnie z wykładnią Księgi Ezdrasza, o pojawieniu się raju, który ma się ukazać zaraz po zwycięstwie nad nieprzyjaciółmi (4 Ezd 7,26) albo nawet niebiańskiego Jeruzalem, utraconego wskutek winy ludzkiej (4 Ezd 13,36). Interesująca jest ostatnia część zdania, która obwieszcza: „ipse disponet qui derelicti sunt". Co oznacza słowo disponet? Komentatorzy dokonują różnych tłumaczeń: ordnen, richten und urteilen, hinüberführen, reducet, erlösen. Najbardziej poprawne wydaje się jednak tłumaczenie "sprowadzić z powrotem” (zob. Iz 49,6), „powstrzymać” (Syr 48,10). Autor Księgi Ezdrasza wyznacza zatem Mesjaszowi podwójne zadanie: uwolnienie świata od grzesznych narodów i ponowne ukonstytuowanie pozostałych plemion w Izraelu. Późniejsze wersety Księgi dodają do tych zadań jeszcze troskę o te plemiona (4 Ezd 13,49-50) ${ }^{37}$.

35 Por. M. Stone, The Concept of the Messiah in IV Ezra, s. 298n.

36 Por. J. Keulers, Die eschatologische Lehre, s. 110.

37 Por. całościowe ujęcie wizji, prezentowana przez U.B. Müller, Messias und Menschensohn, s. 86-154. 
Pewną wskazówkę dają również inne teksty literatury apokaliptycznej. W syryjskiej wersji Apokalipsy Barucha spotykamy sformułowanie bliskie obrazowi Ezdrasza: czas mesjański autor nazywa czasem „troski” rozciągniętej nad „resztą” narodu. Autor używa tutaj sformułowania: „weźmie w opiekę pozostały mój lud” (ApBaSyr 40,2). W dalszej części dzieła Baruch opisuje zwycięstwo nad nieprzyjaciółmi i pokojową intronizację Mesjasza, używając takich określeń, jak „radość” i „spokój” (ApBaSyr 73,1-2). Odnajdujemy tutaj zatem słowo „spokój”, które można było spotkać u Ezdrasza, który używał określenia refrigerium (4 Ezd 11,46).

Wartym zauważenia jest jeszcze jeden fragment $\mathrm{z}$ literatury apokaliptycznej, który jest zbieżny z tekstem Łukasza. Według Przepowiedni Sybilli Bóg pośle ze Wschodu króla, który da wytchnienie ziemi od zła wojny (zob. OrSyb III, $652-653)^{38}$. Wydaje się, że autor mówi tutaj o czasie mesjańskim jako okresie wytchnienia. Mamy zatem do czynienia tutaj z opisem królewskiego mesjanizmu eschatologicznego.

Istotną wydaje się sugestia niektórych biblistów, którzy sugerują, aby sformułowanie kairoi anapsykseōs ujmować w kontekście całego zdania, szczególnie sformułowania apo prosopou tou kyriou. Należy zwrócić uwagę na fakt, że „czasy ochłody” dokonają się „w obliczu Boga” (por. Dz 5,41; 7,45). Według teologów określenie to wskazuje, że dobra zbawcze są przygotowane przez Boga i oczekują w niebie. Podobną myśl można spotkać w Księdze Ezdrasza, gdzie autor stwierdza: ,jest dla was otwarty ogród i zasadzone jest drzewo życia, gotowa przemiana świata i przygotowana przyjemna woń, zbudowane miasto i przysposobione miejsce odpoczynku, wypełnione dobrem i mądrością" (4 Ezd 8,52). Dobra te są przez Boga przygotowane, zatem należy o nich powiedzieć że pochodzą „od Jego oblicza”. Należy stwierdzić zatem, że rzeczywistość zbawcza, zabezpieczona przez Boga w niebie, oczekuje na wypełnienie się czasu zbawienia mesjańskiego, określona przez Łukasza jako kairoi anapsykseōs.

\section{Zakończenie}

Ujmując wszystkie kwestie, należy stwierdzić, że termin anapsyksis, użyty przez Łukasza w Dziejach Apostolskich, jest spotykany w Starym Testamencie oraz wielu tekstach żydowskiej literatury apokaliptycznej. Opisuje on najczęściej czas, w którym jest obecny i działa Mesjasz. Jego osoba oraz przedział czasowy,

38 „A wtedy Bóg od wschodu słońca pośle króla, który na całej ziemi nieszczęsne wojny ugasi, zabijając jednych, drugim nakładając zobowiązujące przysięgi” (OrSyb III, 652-653), 
w którym przejawia się jego aktywność, nazywana jest przez autorów czasem „orzeźwienia/ochłody”.

Najogólniej mówiąc, idea „czasu Mesjasza” jest opisywany przez teksty apokaliptyczne jako „okres pokoju” lub „odpoczynku” (4 Ezd 11,46; ApBaSyr 73,1; OrSyb III,653), połączony z ideą „wyzwolenia od nieprzyjaciół” (4 Ezd 12,34; 13,26.49), „ustąpienia bolesnego wewnętrznego doświadczenia” (ApBaSyr 73,2). Dodatkowo jeszcze można przywołać obrazy mówiące o „opiece” (4 Ezd 13,49; ApBaSyr 40,2), „radości” (4 Ezd 7,28; 12,34; ApBaSyr 73,2) czy też „odnowieniu” (4 Ezd 13,26). Księga Ezdrasza wspomina też o „objawieniu się cudów zbawczych” (4 Ezd 13,26).

Należy stwierdzić, że obszar znaczeniowy terminu kairoi anapsykseōs jest bardzo szeroki, niemniej jednak odnosi się do jednej tylko sfery. Jest to określenie mesjańskiego królestwa eschatologicznego, które posiada swój wymiar czasowy. Jest to królestwo nadziei narodowej a jego beneficjentem ma być Izrael. Cały werset z Dz 3,20 należy interpretować eschatologicznie. Nawołuje on do nawrócenia i pokuty, poprzez które człowiek może spodziewać się dóbr eschatologicznych. Zachowanie prawa jest tutaj imperatywem, ponieważ otwiera perspektywę nadchodzącego czasu zbawienia mesjańskiego. Korzystającymi z tego czasu zbawienia są generalnie ci, którzy „pozostali/przetrwali”. Czas zbawienia nazwany został przez Łukasza czasem „orzeźwieni/ochłody” i misji Mesjasza w świecie. Według Dz 3,19-21 czas zbawienia jest powiązany $\mathrm{z}$ pokutą i nawróceniem. Jest to zgodne $\mathrm{z}$ duchem wypowiedzi literatury międzytestamentalnej, w której powrót do zachowywania Prawa jest scharakteryzowany jako czas pokoju, radości, wolności od Szatana i zła. Wiele fragmentów literatury rabinicznej wiąże temat zachowywania Prawa $\mathrm{z}$ nawróceniem Izraela. Niektóre głoszą wręcz, że początek czasu zbawienia dokona się dopiero po nawróceniu całego Izraela (tekst Sanhedrin 97b mówi: „jeśli Izraelici będą czynić pokutę, zostaną wyzwoleni, jeśli nie, nie zostaną wyzwoleni”). Rabbi Jonatan oświadczył: „nawrócenie to wielka sprawa, ponieważ przynosi wolność" (Joma [Kippurim] 86b).

Ujmując całościowo fragment drugiego przemówienia Piotra (Dz 3,19-21), należy stwierdzić, że mówi on o czasach eschatologicznych. Tekst opisuje moment zbawienia który nastąpi w momencie powrotu Chrystusa. Zbawienie eschatologiczne, zrealizowane w momencie paruzji, będzie najwyższym momentem dopełnienia się historii zbawienia. Jezus powróci jako Ten, który przynosi «czas orzeźwienia» w momencie wypełnienia się wszystkich zapowiedzi Pisma. Śmierć i zmartwychwstanie Chrystusa pojmuje Ewangelista jako dopełnienie proroctw mesjańskich. Do wypełnienia się „wszystkich” Pism brakuje jedynie nawrócenia wszystkich, nawrócenia uniwersalnego, do którego wzywa się „W te dni”. „Te dni” są zatem okresem misjonarskiego trudu, a dni głoszenia 
Łukasz nazywa czasem „orzeźwienia” i „ochłody” - mesjańskim czasem eschatologicznym.

\section{Bibliografia}

Barbi 1.A., Il Cristo celeste presente nella Chiesa. Tradizione e redazione in Atti 3, 19-21, Roma 1979.

Bauernfeind O., Kommentar und Studien zur Apostelgeschichte (WUNT 22), Tübingen 1980.

Bauernfeind O., Tradition und Komposition in dem Apokatastasisspruch Apg. 3,20s. w: O. Betz - M. Hengel - P. Schmidt (red.), Abraham unser Vater. Juden und Christen im Gespräch über die Bibel. Fs O. Michel (AGAJU 5), Leiden-Köln 1963, s. $13-23$.

Cerfaux L., Citations scripturaires et tradition textuelle dans de Livre des Actes, w: AAVV (red.), Aux sources de la tradition chrétienne. Mélanges offerts à Maurice Goguel à l'occasion de son soixante-dixième anniversaire, Neuchâtel-Paris 1950, s. 45-73.

Conzelmann H., Die Mitte der Zeit. Studien zur Theologie des Lukas (BHTh 17), Tübingen ${ }^{5} 1964$.

Dietrich A., Nekyia. Beiträge zur Erklärung der neuentdeckten Petrus-Apokalypse, Leipzig-Berlin ${ }^{2} 1913$.

Dobschütz von E., Die Thessalonicher - Briefe, (KENT 10), Göttingen 1909.

Dupont J., Les discours de Pierre dans les Actes et le chapitre XXIV de l'évangile de Luc, w: F. Neirynck (red.), L'Évangile de Luc. Problèmes littéraires et théologiques. Fs L. Cerfaux, Gembloux 1973, s. 359.

Grässer E., Acta Forschung seit 1960, ThR 42 (1977), s. 2-24.

Grundmann W., Das Evangelium nach Lukas (ThHNT 3), Berlin ${ }^{5} 1969$.

Haenchen E., Die Apostelgeschichte. Neu übersetzt und erklärt (KEKNT 3), Göttingen ${ }^{14} 1968$.

Hahn F., Christologische Hoheitstitel. Ihre Geschichte in frühen Christentum (FRLANT 83), Göttingen ${ }^{3} 1966$.

Keulers J., Die eschatologische Lehre des vierter Esrabuches, Freiburg 1922.

Kliesch K., Die Heilsgeschichtliche Credo in den Reden der Apostelgeschichte (BBB 44), Köln-Bonn 1975.

Lambrecht J., exaleiphō, w: H. Balz - G. Schneider (red.), Dizionario esegetico del Nuovo Testamento, t. 1, Brescia 1995, s. 1239.

Lohfink G., Christologie und Geschichtsbild in Apg. 3,19-21, BZ 13 (1969) 219-231.

Lohfink G., Die Himmelfahrt Jesu. Untersuchungen zu den Himmelfahrts- und Erhöhungstexten bei Lukas, München 1971.

Masson C., Les deux épîtres de saint Paul aux Tessaloniciens, (CdNT 11A), Neuchâtel 1957.

Müller U.B., Messias und Menschensohn in jüdischen Apokalypsen und in der Offenbarung des Johannes, Gütersloh 1972. 
Mussner F., Praesentia salutis. Gesammelte Studien zu Fragen und Themen des Neuen Testamentes, Düsseldorf 1967.

Robinson J.A.T., Jesus and His Coming. The Emergence of a Doctrine, London ${ }^{3} 1967$.

Stone M., The Concept of the Messiah in IV Ezra, w: J. Neusner (red.), Religions in Antiquity. Essays in Memory of Erwin Ramsdell Goodenought, (SHR.S 14), Leiden 1968, s. 293-310.

Strack H.- Billerbeck P., Kommentar zum Neuen Testament aus Talmud und Midrash. II. Das Evangelium nach Markus, Lukas und Johannes und die Apostelgeschichte, München 1965-1969.

Volz P., Die Eschatologie der jüdischen Gemeinde im neutestamentlichen Zeitalter, Hildesheim ${ }^{2} 1966$.

Voss G., Die Christologie der lukanischen Schriften in Grundzügen, Paris-Brügge 1965. Wendt H.H., Die Apostelgeschichte, Göttingen 1899.

Wilckens U., Die Missionreden der Apostelgeschichte. Form- und traditionsgeschichtliche Untersuchungen, (WMANT 5A), Neukirchen-Vluyn ${ }^{3} 1974$.

Zehnle 3. R.F., Peter's Pentecost Discourse. Tradition and Luka Reinterpretation in Peter's Speeches of Acts 2 and 3, Nashville-New York 1971. 